\title{
A Place of Opportunity: Black Male Student Athletes' Experiences at a Historically Black University
}

\author{
Joseph N. Cooper and Billy Hawkins \\ University of Georgia
}

\begin{abstract}
The purpose of this study was to identify key factors associated with the academic achievement and positive college experiences among Black male student athletes at a Historically Black University (HBU) in the Southeastern United States (U.S.). A concurrent triangulation exploratory design allowed both qualitative and quantitative data to be collected simultaneously and converged during the analysis phase (Creswell, 2009). Participants in this study included current Black male student athletes who participated in football and men's basketball at a HBU in the Southeastern U.S. Using aspects of the grounded theoretical approach for analysis (Glaser \& Strauss, 1967), the following emergent themes were identified: "You Got a Chance," "An Opportunity," "Not Just a Number," "It's Hard, But It's Not Impossible" and "As An Athlete It Makes Your Social Life a Little Easier." Implications for policy and practice are discussed.
\end{abstract}

Keywords: Black male student athletes, academic achievement, historically Black colleges and universities (HBCUs)

A longstanding problem facing institutions of higher education has been the persistently low graduation rates of Black male student athletes (Lapchick, 2010, 2011; NCAA, 2010a, 2010b, 2011a, 2011b). For years, critics of the National Collegiate Athletic Association (NCAA) and its member institutions have argued the overemphasis on athletic performance has resulted in the academic and personal underdevelopment of Black male student athletes (Edwards, 2000; Harris, 1994; Hawkins, 2010; Sailes, 2010; Smith, 2009). Black male student athletes at these institutions often encounter unique challenges such as negative stereotypes (e.g., "dumb jock" label), being first-generation college students, coming from lower socioeconomic status backgrounds, as well as being more likely to experience poorer academic preparation entering college (Adler \& Adler, 1991; Brooks \& Althouse, 2000; Harrison \& Lawrence, 2004). Unfortunately, many institutions have not provided adequate support systems or cultivated positive learning environments that take into account the impact of these various challenges. Thus, the low academic achievement of Black male student athletes is less a reflection of individual efforts and largely a result of ineffective institutional practices (Harper, 2012).

The authors are with the Kinesiology Department, University of Georgia, Athens, GA. 
A significant amount of research on Black male student athletes has focused on their experiences and academic achievement at major Division I predominantly White institutions (PWIs) (Comeaux, 2010; Comeaux \& Harrison, 2007; Harrison et al., 2009; Lawrence, 2005; Martin, Harrison, Stone, \& Lawrence, 2010; Singer, 2005). Within this context, Black male student athletes experienced various forms of racial discrimination, social isolation, academic neglect, and athletic exploitation (Brooks \& Althouse, 2000; Edwards, 2000; Hawkins, 2010; Sailes, 2010; Smith, 2009). These negative experiences were further exacerbated by the cultural dissonance experienced by Black male student athletes who attended institutions that were vastly different from their precollege environments (Hawkins, 2010). Consequently, these negative experiences contributed to high attrition rates and poor academic outcomes (Benson, 2000; Lawrence, 2005; Singer, 2005).

Contrarily, previous research on Historically Black Colleges and Universities (HBCUs) indicated these institutions were effective educational environments for Black student athletes to experience positive academic outcomes (American Institutes for Research, 1988, 1989; Brown, 2004; Person \& LeNoir, 1997). For example, recent NCAA reports of Division II institutions reveal the academic success rate for Black male student athletes from HBCU conferences is higher than their contemporaries in other settings ${ }^{1}$ (NCAA, 2011a, 2012a). Given the fact that most Division II schools are PWIs, these statistics illustrate the effectiveness of Division II HBCUs as institutions with athletic departments that are committed to the academic achievement of its Black male football student athletes.

The Mid-Eastern Athletic Conference (MEAC) and Southwestern Athletic Conference (SWAC) are the only two HBCU athletic conferences at the NCAA Division I level. As members of Division I, these conferences are eligible to benefit from the $\$ 845.9$ million revenues, which are largely generated by the NCAA Men's Basketball tournament (NCAA, 2012b). With the current NCAA revenue structure, the farther a team advances in the NCAA Men's Basketball Tournament, the more revenue the team's conference will receive. For example, in 2012, Norfolk State University's (NSU) upset win over the highly favored Missouri Tigers generated $\$ 3.8$ million for the MEAC, which resulted in \$292,000 for NSU (Smith, 2012). The unexpected revenue covered NSU's annual operating expenses and underscored the major upside of fielding competitive men's basketball teams. In an effort to maximize profits, many Division I programs prioritize winning basketball games at the expense of preserving academic integrity and the holistic development of its student athletes. As a result, many Division I schools, including those in Division I HBCU conferences, engage in questionable practices, such as unethical recruiting, academic fraud, and profit-driven conference realignments (Byers, 1995; Lillig, 2009).

In contrast, a number of HBCUs are members of the NCAA's Division II. The Central Intercollegiate Athletic Association (CIAA) and the Southern Intercollegiate Athletic Conference (SIAC) are the two prominent Division II HBCU conferences. Division II institutions sponsor fewer sports, operate with significantly smaller budgets, and do not have the lucrative television contracts and sponsorships that are shared among Division I institutions (Sack \& Staurowsky, 1998). The mission of Division II athletic programs promotes a balanced approach, whereby "students are recognized for their academic success, athletic contributions, and campus/community involvement" (NCAA, 2011c, p.1). Contrary to the corporate professional model of big-time Division I athletic programs, which prioritizes athletic revenue 
generation above student development, Division II programs operate under a true amateur model (NCAA, 2011c; Sack \& Staurowsky, 1998). Rather than disregarding student development, the student centered amateur model at Division II schools promotes a student first and athlete second approach.

This review suggests examining the institutional practices at Division II HBCUs and the experiences of Black male student athletes at these institutions could provide insight into effective strategies for improving the academic achievement and positive college experiences of Black male student athletes. With this in mind, we adopted aspects of grounded theory (Glaser \& Strauss, 1967) to examine the motivations and experiences of Black male student athletes enrolled at a HBU. The following research questions guided this study:

RQ1: What are the motivations for attending a Historically Black University for Black male student athletes?

RQ2: What are the holistic experiences (academic, athletic, and social) of Black male student athletes at a Historically Black University?

RQ3: What factors are associated with Black male student athletes' academic achievement at a Historically Black University?

\section{Methods}

\section{Participants}

The participants $(n=48)$ in this study were current varsity football and men's basketball student athletes from a HBU located in the Southeastern U.S. Since Black male student athletes are overrepresented in the two largest NCAA revenue-generating sports of football and men's basketball, only participants in these two sports were targeted for this study (Brooks \& Althouse, 2000; Edwards, 2000; Hawkins, 2010; Sailes, 2010; Smith, 2009). A purposeful sampling technique was used to identify Black male student athletes who met a certain criteria for this study (Gratton \& Jones, 2010). Participants were selected on the following criteria: (a) identified as Black or African American, (b) a member of either the varsity football and/or men's basketball team at the HBU and (c) currently enrolled as a full-time student at the HBU. There was a $42.5 \%$ percent response rate (48 out of 113). Not all Black male football and basketball student athletes at the targeted institution were available due to schedule conflicts; however, all available and eligible participants consented and completed the Student Athlete Questionnaire (SAQ). A total of seven (three football and four men's basketball) student athletes participated in the focus group portion of this study.

\section{Instrument}

We used quantitative and qualitative means for collecting data. For the former, we used a questionnaire to assess the student athletes' classification/year in school; racial demographic of high school; family background; estimated high school grade point average (GPA); estimated family socioeconomic status; estimated college cumulative GPA; current/prospective major; primary major choice; and primary college choice. The latter (i.e., the qualitative approach) involved a single focus group interview with seven Black male football (three) and men's basketball (four) 
student athletes. The use of a focus group was appropriate for this study because focus groups provide a context for dialogical conversations to occur in the construction of new knowledge as well as serve as a useful technique for examining the collective experiences of a group of participants (Denzin \& Lincoln, 2005). Following the administration of the questionnaire, each participant's completed questionnaire was numerically and color-coded based on their reported cumulative college grade point average (GPA). The color of the paper the participants were assigned represented which GPA range they reported (e.g., 2.00 or below (yellow), 2.01-2.49 (orange), 2.50-2.99 (green), 3.00 and above (blue)). This process was used to ensure the focus group participants were representative of all reported GPA ranges (e.g., 2.00 or below; 2.01-2.49; 2.50-2.99; 3.00 and above). Once all questionnaires were submitted, participants across the four GPA ranges were solicited for participation in the focus group interview. Among focus group participants, one reported a 2.00 or below cumulative college GPA, one reported a 2.01-2.49 cumulative college GPA, four reported a 2.50-2.99 cumulative college GPA, and one participant reported a 3.00 or above cumulative college GPA.

\section{Data Analysis}

We computed descriptive statistics related to the participants' background and demographic information (see Table 1). We then used these findings to complement the qualitative analyses and findings.

Qualitative data from the focus group interviews were analyzed by using aspects of the grounded theoretical approach to analysis (Charmaz, 2006; Corbin \& Strauss, 1990; Glaser \& Strauss, 1967). This analytical process involved the use of open, axial, selective, and thematic coding processes to identify emergent themes from the focus group interview. The researchers also used memos and constant comparative analyses throughout the coding process to ensure precise coding refinement (Corbin \& Strauss, 1990). Data and methodological triangulation were used during the data collection, interpretation, and analysis phases of this study (Greene, 2007).

During the open coding process, the researchers reviewed the transcript multiple times and created an exhaustive list of codes for the participants' responses to each question. In vivo coding was applied during this process to ensure the codes were grounded in the data (Corbin \& Strauss, 1990; Glaser \& Strauss, 1967; Martin et al., 2010; Ryan \& Bernard, 2000). In other words, each open code was conceptualized with an exact word or phrase from the participants' responses. For example, the code "basketball" represented a response that indicated the participant's primary motivation for attending the HBU was related to athletics. The next step involved the axial coding process, whereby responses were categorized into separate constructs. The following constructs were assigned with corresponding numeric codes: (a) "basketball/football" (motivations for attending an HBU; 100 level codes), (b) "a good feeling" (holistic college experiences; 200 level codes), (c) "an individual" (college academic experiences; 300 level codes), (d) "tough/ hard" (college athletic experiences; 400 level codes), and (e) "better" (college social experiences; 500 level codes).

During the selective coding process, "poorly developed categories" were either clustered with more salient codes or coded as less salient (Corbin \& Strauss, 1990, p. 14). All selective codes were analyzed for both patterns as well as uncommon responses. For example, the code "location" was an open code that was identified 
Table 1 Demographic Results

\begin{tabular}{|c|c|}
\hline Item & Percentage $(N=48)$ \\
\hline \multicolumn{2}{|c|}{ Classification/Year in School } \\
\hline Freshman & 31.3 \\
\hline Sophomore & 14.6 \\
\hline Junior & 14.6 \\
\hline Senior & 20.8 \\
\hline Did Not Indicate & 18.8 \\
\hline \multicolumn{2}{|c|}{ High School Racial Make-Up } \\
\hline Mostly Black & 77.1 \\
\hline Mostly White & 8.3 \\
\hline Mixed & 10.4 \\
\hline Did Not Indicate & 4.2 \\
\hline \multicolumn{2}{|l|}{ Family Background } \\
\hline Two parents & 54.2 \\
\hline One parent & 39.6 \\
\hline Two guardians & 4.2 \\
\hline One guardian & 2.1 \\
\hline \multicolumn{2}{|c|}{ Estimated High School GPA } \\
\hline 2.00 or below & 10.4 \\
\hline $2.01-2.49$ & 20.8 \\
\hline $2.50-2.99$ & 41.7 \\
\hline 3.00 or above & 25.0 \\
\hline Did Not Indicate & 2.1 \\
\hline \multicolumn{2}{|c|}{ Family Annual Household Income* } \\
\hline$\$ 34,999$ or below & 52.1 \\
\hline$\$ 35,000-\$ 74,999$ & 22.9 \\
\hline$\$ 75,000-\$ 99,999$ & 10.4 \\
\hline$\$ 100,000$ or above & 8.3 \\
\hline Did Not Indicate & 6.3 \\
\hline \multicolumn{2}{|l|}{ Estimated College GPA } \\
\hline 2.00 or below & 12.5 \\
\hline $2.01-2.49$ & 39.6 \\
\hline $2.50-2.99$ & 33.3 \\
\hline 3.00 or above & 14.6 \\
\hline \multicolumn{2}{|c|}{ Current/Prospective Major } \\
\hline Business & 20.8 \\
\hline Computer Science & 8.3 \\
\hline Engineering & 4.2 \\
\hline Humanities & 22.9 \\
\hline Music & 2.1 \\
\hline Physical Science & 8.3 \\
\hline Social Science & 33.3 \\
\hline
\end{tabular}


Table 1 (continued)

\begin{tabular}{lc}
\hline Item & Percentage $(N=\mathbf{4 8})$ \\
\hline Current Major was Primary Choice & \\
Strongly Disagree & 6.3 \\
Disagree & 27.1 \\
Agree & 35.4 \\
Strongly Agree & 25.0 \\
No Response & 6.3 \\
Primary College Choice & \\
Current HBU & 8.3 \\
D-I HBCU & 12.5 \\
D-II HBCU & 2.1 \\
D-I PWI & 56.3 \\
D-II PWI & 6.3 \\
D-III PWI & 4.2 \\
Military & 4.2 \\
Other & 6.3 \\
\hline
\end{tabular}

*Income levels were adjusted and based on findings from the following reference: DeNavas-Walt, C., Proctor, B.D., Smith, J. C. (2011)[AUQ6]. U.S. Census Bureau, Current Population Reports. Income, Poverty, and Health Insurance Coverage in the United States: 2010. U.S. Government Printing Office: Washington, DC. p. 60-239.

as less salient in regards to the participants' motivations for choosing to attend a HBU. Whereas, the code "coach" was merged into the "basketball/football" construct to signify the participants' primary motivation for choosing to attend a HBU was related to athletics. The final stage involved the thematic coding process, which allowed the researchers to reorganize the data into the emergent themes (Denzin \& Lincoln, 2005).

\section{Results}

Five emergent themes were identified from the focus group interview: (a) "You Got a Chance," (b) "An Opportunity, (c) "Not Just a Number," (d) "It's Hard, But It's Not Impossible," and (e) "As An Athlete It Makes Your Social Life a Little Easier." In vivo coding was used to ensure the data were grounded in the participants' responses (Corbin \& Strauss, 1990; Glaser \& Strauss, 1967; Martin et al., 2010; Ryan \& Bernard, 2000).

\section{"You Got a Chance"}

The first research question of this study focused on identifying the motivations of Black male student athletes who chose to attend a HBU. In response to this question, the most salient theme among the participants' responses was the notion that this HBU, "Mission University (MU)," ${ }^{2}$ provided them with an athletic opportunity to excel in their primary sport. Although, four of the seven participants received 
athletic scholarship offers from other schools, they chose to attend this HBU rather than a Division I PWI. The quote "you got a chance" came from Greg, a sophomore basketball player, when he described his motivations for choosing to attend MU:

You know you gotta go somewhere... where I see it as you're going to standout over time. You know D-I programs they're gonna bring in good players from all over the world... whereas in D-II you got a chance to make a name for yourself over time.

According to Greg, he could have attended a more nationally recognized program, but he received a better chance at excelling athletically at MU. The theme of "you got a chance" also related to the fact that MU provided participants with a opportunity to attend college in light of mitigating circumstances. Austin, a senior basketball player, described his journey to MU:

Coming out of high school I had been committed to another institution [Division I PWI] and got in a little trouble....and it was like Black folks were the only ones who were still really giving me a chance so when life changed I just decided to go to an HBCU.

Although, each participant had a different reason for attending MU, six out of the seven focus group participants expressed they attended MU because it was place that provided them with a chance to play their primary sport at the college level.

\section{"An Opportunity"}

The second research question pertained to understanding the holistic experiences of Black male student athletes at a HBU. In regards to participants' overall college experience, the consensus among the focus group was MU served as a place of opportunity for them to develop holistically. Greg explained the unique opportunity he received at $\mathrm{MU}$ :

[Y]ou just get more of an opportunity...you know you're treated more as an equal ....instead of like a number...you know you get relationships with your professors together...you just get a better opportunity...more connections... you can get more friends...more social life...just a bigger gathering.

This quote highlights how Greg felt the educational environment at MU was positive and supportive. He felt his professors cared about his success beyond the classroom. Quinton, a first year football player, captured the focus group's sentiment about the psychosocial benefits of attending a HBU rather than a PWI:

I feel like it's good to come to an HBCU. Like let's say you go to an all-White school...to the teachers there you are just a number to them...like you can't get a relationship with your professors or anything. But you come to an HBCU you can get in good with your teachers... and you can meet good people here... it's a good feeling.

Drew, a senior basketball player, expounded on the uniqueness of the HBCU environment and how it influenced his college experiences: 
I mean it's safe to say there is really no other experience like the HBCU experience. It's a different feeling ... you feel a sense of proud history...like you're a part of something that's big especially with it being at an HBCU. So, it's definitely a positive thing to remember the rest of your life.

Interestingly, $77.1 \%$ of participants who completed the questionnaire attended a predominantly Black high school. Within this type of educational environment, these participants might have felt comfortable and supported. These findings indicated the environment at MU created a feeling of opportunity and optimism among the participants that positively contributed to their overall college experiences and academic achievement.

\section{"Not Just a Number"}

The theme "Not Just a Number" emerged from the participants' responses to questions about their academic experiences and factors related to their academic achievement. In conjunction with this theme, three subthemes were identified from the participants' responses: (a) the benefit of small classes, (b) the prevalence of positive relationships with professors, and (c) academic support programs. Related to small classes, Drew explained how the smaller class sizes contributed to his academic experiences:

You can have a relationship with your professors so you're not just a number... I know at some of the big schools it's like almost like a hundred people in classes...so it's definitely a...good experience as far as getting in tune with your work.

Along the same lines, Greg explained how the professors at MU displayed an ethic of care and nurture:

They give you a better opportunity... like your teachers are more worried about you actually graduating or actually getting what you need done...If you need something it's to your benefit to go to the teacher because you know they'll help you. They'll help to their best ability...that's what I observed here at a HBCU.

This quote is particularly poignant because it highlights the fact that professors at MU are committed to the educational mission of the institution. Moreover, the participants' referenced three academic support services they felt benefited them academically: (a) study groups with student athlete tutors, (b) TRIO (federally funded outreach program operated at the university level), and (c) the Writing Center. Greg described how the study groups within the athletic department were helpful:

$[\mathrm{O}] \mathrm{n}$ the athletic side we all got study groups... we've got tutors... so let's say like someone is struggling in a class...you got the connection...you can go to somebody who is good at that class... You know they know your situation with athletics.

As student athletes, they had access to academic support services specifically designed to take into account their athletic schedules and commitments. Kenneth, 
a first year football player, described how he benefited from working with the TRIO program:

I'm in TRIO services...student support services... and they came to me when I first got here...I came here in the summer time as a freshman...you know I wasn't doing too good...I had like a 2 point...2.5 or something like that...but when I got with them it just helped me...they helped to get my GPA up to a 3.0.

Austin also explained the benefits of using a university-wide academic support program, the MU Writing Center:

[T] he Writing Center...they help you with papers....all you got to do is take it them... they go over every word with you...I feel like that's one of the best academic helps that the school got...

Among the focus group participants, five of the seven participants had an estimated college GPA of 2.50 or above. Correspondingly, nearly one-half of the questionnaire respondents $(47.9 \%)$ had an estimated college GPA of 2.50 or above. The personal connections with MU faculty and academic support staff created feelings of trust, confidence, and motivation among these participants. A key element within each aspect of the academic support programs was every faculty and staff member expressed a genuine interest in the participants' holistic development rather than simply their athletic ability.

\section{"It's Hard, But It's Not Impossible"}

Another part of the second research question relates to understanding the impact athletic experiences have on the academic experiences of Black male student athletes at a HBU. The emergent theme, "It's Hard, but it's Not Impossible," refers to the difficult task of trying to balance the dual roles of being a student and an athlete while in college. Drew explained how the time commitment associated with athletics makes it difficult for him to focus on his academics:

...it's hard being on that road...traveling almost 10 hours...it's hard sometimes to get up the energy to do your work [academic work]...it's tough...we are blessed to really have the help from some of our teachers as far as everything is concerned.

Particularly at the Division II level, many of the away games for teams involve long bus rides since many of these schools cannot afford to fly to away games like larger well-funded Division I schools. These athletic commitments are not only time consuming, but also physically demanding. Shaun accurately captured the focus group's sentiments about their athletic experiences when he said: "It's hard, but it's not impossible."

Additional findings revealed the environment at this Division II HBU also promoted a healthy balance between being a student and an athlete. Similarly, all focus group participants agreed attending class and performing well academically was a standard expectation at MU. They understood that as student athletes their responsibilities as students preceded their athletic responsibilities. Therefore, despite the constraints of time commitment associated with athletics, these participants felt overall their athletic participation positively influenced their college experiences. 


\section{"As An Athlete, It Makes Your Social Life a Little Easier"}

The third aspect of research question two pertained to understanding the social experiences of Black male student athletes at a HBU. The most salient theme from the participants' responses was the idea that "As an Athlete, It Makes Your Social Life a Little Easier." According to the focus group, their athletic participation served as their primary form of social involvement in college. This involvement provided them with privileges based on their athletic status. For example, in response to the question about how their social experiences affected their academic and athletic experiences in college, Austin said: "For me, I would say my athletic experiences have affected my social experiences. Like coming in getting a little name as an athlete, it makes your social life a little easier..." Similarly, Greg explained how being an athlete affected his social experiences at MU:

Just being an athlete period it makes things easier especially when you're good at something...it's that much better because people know you...being an athlete for one and a good athlete at that...makes it a lot easier.

Moreover, it is interesting to note four out of the seven focus participants also participated in extracurricular organizations. Scottie was involved in both an oncampus and off-campus social organization. Austin was a member of a campus service organization. Drew and Shaun were both members of academic organizations related to their respective majors. Although these four participants were involved in at least one extracurricular organization, the consensus among the group was their athletic participation was their preferred form of social involvement on campus.

\section{Discussion}

The purpose of this study was to identify key factors associated with the academic achievement and positive college experiences of Black male student athletes at a HBU in the Southeastern U.S. The first research question focused on identifying the motivations for attending a HBU. Findings revealed the participants in this study primarily attended this HBU because it provided them a "chance" to play their primary sport at the intercollegiate level. Nearly all of the focus group and $56.3 \%$ of questionnaire respondents reported their primary college choice was a Division I PWI. In contrast, only $22.9 \%$ reported an HBCU as their primary college choice. A possible explanation for the overwhelming interest in attending a major Division I PWI could be the increased exposure and resources available at those schools would provide them with the best opportunity to make it to the professional ranks (e.g., National Basketball Association [NBA] or National Football League [NFL]). A majority of the participants in this study (52.1\%) grew up in low-income households ( $\$ 34,999$ or below annual household income), and thus, may view athletics as a viable option for upward social mobility (Smith, 2009). The reality is the chances of making it to the professional ranks are miniscule. Yet, even at a Division II school, all of the focus group participants still felt it was a very real possibility for them to make it to the NBA or NFL.

On the other hand, the focus group participants also acknowledged the importance of education. They understood being a student athlete provided them with an opportunity to develop themselves beyond their athletic abilities. Austin epitomized this sentiment when he said: "You also gotta another goal in mind...." 
The environmental cues conveyed by the MU faculty and staff let these participants know that they were valued as students first (Steele, 2010). Kenneth also described how professors at MU did not show them preferential treatment because they were athletes when he said: "teachers don't care about if you are a football player or basketball player." These findings reinforced the tenets of Division II institutions and the role intercollegiate athletics fulfill within the broader educational mission of each member institution (NCAA, 2011c).

The second research question focused on understanding the holistic experiences (academic, athletic, and social) of Black male student athletes at a HBU. From the focus group interview, all the participants viewed their experience at MU as a better "opportunity" for them to excel academically, athletically, and socially. Specifically, they felt they had a better opportunity to develop positive and meaningful relationships with their professors, classmates, staff, and others affiliated with the university. The positive experiences of the participants were directly attributed to the environment at MU. Drew characterized the consensus among the focus group about attending a HBU when he said "it's safe to say there is really no experience like the HBCU experience." The positive identity affirmation these student athletes received at this HBU indicated the institutional agents at MU valued them holistically. The institutional agents, specifically faculty and staff, fostered a nurturing environment that was sensitive to the needs of its students while maintaining high expectations (Allen, 1992; Allen, Jewel, Griffin, \& Wolf, 2007; Gallien \& Peterson, 2005; Palmer \& Young, 2010). As a result, the educational environment at MU positively contributed to the academic achievement and enhanced social capital of the Black male student athletes in this study (Palmer \& Gasman, 2008).

Considering academic experiences, the theme "Not Just a Number" suggested these participants not only felt valued as students at MU, but also felt the institutional faculty and staff were committed to their holistic development. The focus group participants described how their professors demonstrated a genuine interest in their academic success and personal development. These findings support previous studies that suggested when Black students felt comfortable and valued in an educational setting they tend to excel academically (Bonner, 2010; Gallien \& Peterson, 2005; Strayhorn \& Terrell, 2010). In addition, these Black male student athletes benefited from small classroom sizes, the use of student athlete academic support programs, and university-wide academic support services (e.g., TRIO and the MU Writing Center).

Connected to athletic experiences, findings from this study revealed participants experienced difficulty balancing their academic and athletic responsibilities. Participants in the study indicated they spent more time on athletics compared with academics. These findings are consistent with previous researchers, who found that the time commitment associated with intercollegiate athletic participation is a primary reason for student athletes' academic underachievement (Adler \& Adler, 1991; Singer, 2008; Zimbalist, 2001). Related to social experiences, findings suggested these participants viewed their athletic participation as their primary and preferred form of social involvement. The consensus among the focus group was that "As an Athlete, It Makes Your Social Life a Little Easier.' Given that four out of seven focus group participants were upperclassmen (juniors or seniors), this finding supports the claim sustained athletic participation in college can contribute to positive social outcomes. For example, Taylor (1995) found that athletic participation contributed 
to higher levels of self-esteem. As an athlete, participants in the current study felt their athletic status granted them access to establishing meaningful relationships on campus. These findings corroborate with previous studies that found athletic participation contributed to stronger peer relationships, increased engagement with students from diverse backgrounds, and overall openness to diversity and challenge (Kuh, 2001; Umbach, Palmer, Kuh, \& Hannah, 2006; Whitt, Edison, Pascarella, Terenzini, \& Nora, 2001; Wolf-Wendell, Toma, \& Worphew, 2001).

Regarding research question three, findings revealed factors such as positive relationships with professors, small classes, and the use of effective academic support programs contributed to academic achievement of the participants in this study. The theme, "Not Just a Number," suggested these participants felt valued by the staff at MU and believed the institution had a stake in their holistic development. The focus group participants cited how they felt their professors genuinely cared about them as individuals. Previous researchers of HBCUs have suggested the faculty at these institutions viewed their students as family, and thus, possessed a strong interest in their holistic development (Allen, Jewel, Griffin, \& Wolf, 2007; Fleming, 1984; Gallien \& Peterson, 2005; Gurin \& Epps, 1975). More specifically, the nature of the faculty-student athlete interactions at MU (both inside and outside of the classroom) had a significant impact on the academic achievement and experiences of the Black male student athletes in this study (Comeaux \& Harrison, 2007; Harrison, Comeaux, \& Plecha, 2006; Pascarella \& Terenzini, 2005).

The participants also expressed how the small classes made it easier for them to develop positive and meaningful relationships with their professors. The smaller classes, coupled with the caring faculty, fostered positive academic experiences for the participants. In other words, the positive and supportive educational environment at MU served as a nurturing "village" for these Black male student athletes to develop and thrive (Palmer \& Gasman, 2008, p. 52). Moreover, as student athletes these participants had access to various academic support services, which proved to be effective for improving their academic achievement. Similarly, Pascarella, Edison, Hagedorn, Nora, and Terenzini (1996) found that intercollegiate athletic participation was one factor positively associated with college students' development of internal locus of attribution for academic success during their first year. More specific to this study, academic support services such as study groups within the athletic department (e.g., with student athlete tutors), TRIO (Federal Outreach Program operated at the university level), and the MU Writing Center (universitywide academic support service) were identified as effective programs related to the participants' academic achievement. Overall, findings from this study indicated athletic participation and the resources associated with being a student athlete enhanced Black male student athletes' academic self-efficacy, experiences, and achievement (Hildenbrand, Sanders, Leslie-Toogood, \& Benton, 2009).

However, it is important to note that the findings of this study are not unique to HBCUs. Several PWIs consistently graduate Black students at high rates (Journal of Blacks in Higher Education, 2008). Rather the emergent findings of this study support Brown's (2004) assertion that the type of school (e.g., HBCU or PWI) is not as important as the effective integration of the student athlete into the academic culture, positive perceptions of institutional support, strong peer relationships, and effective study habits. The fact that these findings were identified at a HBU simply reinforces the notion that HBCUs remain positive and supportive learning 
environments for Black students to thrive academically, athletically, and socially (Allen \& Jewel, 2002; Fleming, 1984; Gurin \& Epps, 1975; Kim, 2002; Kim \& Conrad, 2006; Nettles \& Perna, 1997; Palmer \& Gasman, 2008).

Furthermore, the findings of this study are insightful to the current body of literature on Black male student athletes for two primary reasons. First, there is a conspicuous dearth of research on Black male student athletes at HBCUs (American Institutes for Research, 1988, 1989; Brown, 2004; Person \& LeNoir, 1997). Historically, HBCUs have been culturally relevant and educationally empowering environments for Black students to develop and succeed (Fleming, 1984; Gallien \& Peterson, 2005; Gurin \& Epps, 1975). Examining best practices at HBCUs specifically related to Black male student athletes' academic achievement and positive college experiences is vital for identifying, enhancing, and implementing effective institutional strategies at all U.S. institutions of higher education.

Secondly, this study is unique because the findings and recommendations are grounded in the experiences of the participants (Charmaz, 2006; Corbin \& Strauss, 1990; Glaser \& Strauss, 1967). The use of a mixed methods approach allowed the participants' holistic experiences to be analyzed from multiple perspectives, and thus provided a more comprehensive understanding of their complex experiences (Greene, 2007; Hall \& Ryan, 2011). By using their experiences as a measure of institutional effectiveness, it allows college administrators, faculty, and staff to better develop and enhance effective intervention strategies. All institutional agents at MU were committed to the holistic development of the Black male student athletes in this study. Therefore, this study serves as an example of how one institution, in this case a HBU, successfully cultivates a positive learning environment for Black male student athletes to thrive holistically.

\section{Limitations}

One limitation associated with this study is the use of reported college GPA as the measure of academic achievement. Identifying learning outcomes and experiences of student athletes should not be limited to GPA; however, previous studies on student athletes often used GPA, GSRs, or Academic Progress Rates (APRs) to measure student athletes' academic achievement (Astin, 1993; Harper, 2006; Lapchick, 2011; Pascarella \& Terenzini, 2005; Person \& LeNoir, 1997). Another limitation associated with this study, due to the time constraints and resources, was the limited sample of current Black male football and basketball student athletes at the one HBU in the Southeastern U.S. Therefore, findings from this study cannot be generalized to student athletes at all institutions. In addition, findings from this study do not provide an all-inclusive solution to the complex challenges facing all Black male student athletes at institutions of higher education in the U.S.

\section{Conclusion}

In conclusion, the current study contributes to the current body of research on Black male student athletes by providing insight into their experiences within the unique environment of a HBU. In concert with the tenets of the grounded theoretical approach to analysis (Glaser \& Strauss, 1967), the researchers' used the data from this study to propose a Nurturing Community Hypothesis $(\mathrm{NCH})$, which refers to 
an educational environment that contributes to positive student athlete outcomes through the promotion of holistic identity development in policy and practice. The $\mathrm{NCH}$ builds on previous research, which highlighted the impact of a strong institutional commitment, presence of caring faculty, and positive campus environments on Black male student athletes' college experiences and academic achievement (Bonner, 2010; Person \& LeNoir, 1997). More importantly, the NCH is relevant to both HBCUs and PWIs because the prioritization of student athletes' holistic development should be a part of every athletic department that operates under an educational mission of an institution of higher education in the U.S.

The findings of this study reinforced the NCH because the participants' experiences at MU indicated they felt valued as holistic individuals and not just as athletic gladiators (Edwards, 2000). The NCH is grounded in the participants' responses to the focus group interview questions as well as the SAQ results (Charmaz, 2006; Corbin \& Strauss, 1990; Glaser \& Strauss, 1967). Greg accurately described the practice of the NCH at MU when he said: “...your teachers are more worried about you actually graduating or actually getting what you need done... They'll help to their best ability." The critical mass of caring Black faculty, staff, and peers at this HBU along with the positive affirmation of their multiple identities (e.g., high expectations as students, understanding of their special needs, etc.) allowed these Black male student athletes to experience positive academic, athletic, and social outcomes (Brown, 2004; Person \& LeNoir, 1997; Steele, 2010).

\section{Implications for Policy and Practice}

Using the experiences of these Black male students athletes provides insight into possible strategies aimed at improving their holistic experiences (academic, athletic, and social) and academic achievement at institutions of higher education in the U.S. Although the findings of this study cannot be generalized to all U.S. institutions, all educators of Black male student athletes (e.g., administrators, faculty, and staff) should consider the following implications for policy and practice. One recommendation for improving the educational experiences and academic achievement of Black male student athletes is to establish or strengthen university-wide student support services and athletic department academic support programs. Findings from this study revealed participants benefited from both university wide student support services (e.g., TRIO and the Writing Center) as well as the athletic department academic support programs (e.g., study groups and student athlete tutors). Since, both university-wide student and athletic department academic support services have similar goals, it would be beneficial for these departments to collaborate on effective strategies designed to improve academic achievement among Black male student athletes. The establishment of this type of partnership could maximize university resources, strengthen the connection between the university and the athletics department, and ultimately increase success outcomes for Black male student athletes (academically, athletically, and socially).

Similarly, longitudinal student assessments should be administered from the preenrollment period through graduation to assess student athletes' academic progress and identify specific needs. These assessments could be administered on a semester basis to ensure progress is maintained and issues are identified and resolved in a timely manner. For example, Person and LeNoir (1997) identified three 
models of effective retention programs of African American student athletes. A key aspect of each model involved the oversight by faculty members and/or a student affairs professional. Effective components of these models included academic-year support services, faculty mentoring, personal counseling, summer research and internship opportunities, graduate school preparation workshops, and professional career development services. These assessments should be intentionally designed and longitudinal in nature to ensure precollege characteristics are taken into account, but also to measure progress upon enrollment and through graduation (Comeaux \& Harrison, 2011; Harper, 2012).

In addition, athletic departments should create a protocol where student athletes routinely meet with professors throughout the semester outside of class to establish meaningful relationships. Harrison, Comeaux, and Plecha (2006) recommended institutions implement a wide range of mandatory formal and informal faculty-student interactions and mentoring programs for all student athletes. Several researchers have suggested the extent and nature of faculty-student relationships has a significant impact on students' academic achievement and overall experiences in college (Comeaux \& Harrison, 2007; Harrison et al., 2006). Furthermore, the presence of strong relationships with faculty as well as athletic administrators and staff could enhance the level of commitment and satisfaction among Black male student athletes (Person \& LeNoir, 1997).

Another recommendation for institutions is to develop and/or strengthen programs that cultivate positive holistic development for student athletes. Participants in this study viewed their participation in athletics as their primary and preferred form of social involvement on campus. Thus, using their athletic affiliation as the starting point, programs for student athletes could include graduate school information sessions, professional development workshops, and career exploration activities. Similar to previous recommendations these programs could work in concert with university-wide services and departments to optimize resources and increase the likelihood of success outcomes for participants (Gallien \& Peterson, 2005; Palmer \& Gasman, 2008; Person \& LeNoir, 1997). The primary lesson learned from the experiences of the participants in this study is that when well-coordinated institutional efforts are specifically designed and implemented by caring faculty and staff Black male student athletes can experience a true opportunity to develop and thrive holistically.

\section{Future Research}

Currently there is a scarcity of research on Black male student athlete experiences at HBCUs (American Institutes for Research, 1988, 1989; Brown, 2004; Person \& LeNoir, 1997). Future research should examine the relationship between institutional environments and academic achievement among Black male student athletes at other HBCUs across different divisions (e.g., Division I and II). Additional studies should also include Black male student athletes at PWIs to compare their experiences to those who attend HBCUs. Future studies should also include a larger sample size of participants including students who are not athletes, student athletes across different sports (e.g., track and field, baseball, swimming, tennis), and students across different racial groups (e.g., Black, White, Hispanic, Asian, and so on). In addition, a longitudinal study such as ethnography of a smaller sample of Black male student athletes from precollege through postcollege experiences 
could also provide useful insight in effective strategies and key factors related to their academic achievement and positive college experiences.

\section{Notes}

1. Data for Black male football student athletes from Division II institutions was retrieved from the following source: NCAA (2011a). Trends in academic success rates and federal graduation rates at Division II institutions. Retrieved from http://www.ncaa.org/wps/wcm/connect/public/ NCAA/PDFs/2011/Trends+in+Academic+Success+Rates+and+Federal+Graduation+Rates+at +NCAA+Division+II+Institutions

Data for Black male football student athletes from the Division II HBCU conferences was collected and aggregated from the following source: NCAA. (2012a). GSR/ASR Database. NCAA website. Retreived June 1, 2012 from http://fs.ncaa.org/Docs/newmedia/public/rates/index.html 2. In an effort to provide anonymity of the institutions and participants used for this study, directional institutional pseudonyms were assigned to each respective institution based on geographical location in the state they are located in the southeastern United States.

\section{References}

Adler, P.A., \& Adler, P. (1991). Backboards and blackboards: College athletics and role engulfment. New York: Columbia University Press.

American Institutes for Research. (1988). Summary results from the 1987-1988 national study of intercollegiate athletics. Studies in Intercollegiate Athletics. (Report No. 1). Palo Alto, CA: Center for the Study of Athletics.

American Institutes for Research. (1989). The experiences of Black intercollegiate athletes at NCAA division I institutions. Studies in Intercollegiate Athletics. (Report No. 3). Palo Alto, CA: Center for the Study of Athletics.

Allen, W.R. (1992). The color of success: African American college students outcomes at predominantly White and historically Black public colleges and universities. Harvard Educational Review, 62(1), 26-44.

Allen, W.R., \& Jewel, J.O. (2002). A backward glance forward: Past, present, and future perspectives on historically Black colleges and universities. Review of Higher Education, 25(3), 241-261. doi:10.1353/rhe.2002.0007

Allen, W.R., Jewel, J.O., Griffin, K.A., \& Wolf, D.S. (2007). Historically Black colleges and univerisities: Honoring the past, engaging the present, touching the future. The Journal of Negro Education, 76(3), 263-280.

Astin, A.W. (1993). What matters in college: Four critical years revisted. San Fracisco. Jossey-Bass.

Benson, K. (2000). Constructing academic inadequacy: African American athletes' stories of schooling. The Journal of Higher Education, 71(2), 223-246. doi:10.2307/2649249

Bonner, F.A. (2010). Focusing on achievement: African American student persistence in the academy. In T.L. Strayhorn \& M.C. Terrell (Eds.), The evolving challenges facing Black college students: New insights for practice and research (pp. 66-84). Sterling, VA: Stylus.

Brooks, D., \& Althouse, R. (2000). Racism in college athletics: The African American athlete's experience (2nd ed.). Morgantown, WV: Fitness Information Technology.

Brown, J.M. (2004). Perceptions and performance of African American male student-athletes at a historically Black university and a predominantly White university. (Doctoral Dissertation, Raleigh, North Carolina State University). Retreived June 15, 2012 from http://repository.lib.ncsu.edu/ir/bitstream/1840.16/3751/1/etd.pdf 
Byers, W. (1995). Unsportsmanlike conduct: Exploiting college athletes. Ann Arbor, MI: The University of Michigan Press.

Charmaz, K. (2006). Constructing grounded theory: A practical guide through qualitative analysis. Thousand Oaks, CA: Sage.

Comeaux, E. (2010). Racial differences in faculty perceptions of collegiate student-athletes' academic and post-undergraduate achievement. Sociology of Sport Journal, 27, 390-412.

Comeaux, E., \& Harrison, C.K. (2007). Faculty and male student-athletes: Racial differences in the environmental predictors of academic achievement. Race, Ethnicity and Education, 10(2), 199-214. doi:10.1080/13613320701330726

Comeaux, E., \& Harrison, C.K. (2011). A conceptual model of academic success for studentathletes. Educational Researcher, 40(5), 235-245. doi:10.3102/0013189X11415260

Corbin, J., \& Strauss, A. (1990). Grounded theory research: Procedures, canons, and evaluative criteria. Qualitative Sociology, 13(1), 3-21. doi:10.1007/BF00988593

Creswell, J.W. (2009). Research design: Qualitative, quantitative, and mixed methods approaches (3rd ed.). Los Angeles, CA: Sage.

DeNavas-Walt, C., Proctor, B.D., Smith, J. C. (2011). U.S. Census Bureau, Current Population Reports. Income, Poverty, and Health Insurance Coverage in the United States: 2010. U.S. Government Printing Office: Washington, DC. p. 60-239.

Denzin, N.K., \& Lincoln, Y.S. (2005). The sage handbook of qualitative research (3rd ed.). Thousand Oaks, CA: Sage Publications.

Edwards, H. (2000). Crisis of Black athletes on the eve of the 21st century. Society, 37(3), 9-13. doi:10.1007/BF02686167

Fleming, J. (1984). Blacks in college. San Francisco: Jossey-Bass Publishers.

Gallien, L.B., \& Peterson, M.S. (2005). Instructing and mentoring the African-American college student: Strategies for success in higher education. New York, NY: Pearson.

Glaser, B.G., \& Strauss, A.L. (1967). Discovery of grounded theory: Strategies for qualitative research. Chicago, IL: Aldine.

Gratton, C., \& Jones, I. (2010). Research methods for sport studies (2nd ed.). New York, NY: Routledge.

Greene, J.C. (2007). Mixed methods in social inquiry. San Francisco, CA: John Wiley \& Sons, Inc.

Gurin, P., \& Epps, E.G. (1975). Black consciousness, identity and achievement. New York: Wiley.

Hall, J.N., \& Ryan, K.E. (2011). Educational accountability: A qualitatively driven mixedmethods approach. Qualitative Inquiry, 17(1), 105-115. doi:10.1177/1077800410389761

Harper, S. (2006). Black male students at public flagship universities in the U.S. status, trends, and implications for policy and practice. Washington, DC: The Joint Center for Political and Economic Studies Health Policy Institute.

Harper, S. (2012). Black male student success in higher education: A report from the National Black Male College Achievement Study. Philadelphia, PA: University of Pennsylvania Center for the Study of Race and Equity in Education.

Harris, O. (1994). Race, Sport, and Social Support. Sociology of Sport Journal, 11(1), 40-50.

Harrison, C.K., Comeaux, E., \& Plecha, M. (2006). Faculty and male football and basketball players on university campuses: An empirical investigation of the "intellectual" as mentor to the student-athlete. Research Quarterly for Exercise and Sport, 77(2), 277-284. PubMed doi:10.5641/027013606X13080769704767

Harrison, C.K., \& Lawrence, S.M. (2004). College students' perceptions, myths, and stereotypes about African American athleticism: A qualitative investigation. Sport Education and Society, 9(1), 33-52. doi:10.1080/1357332042000175809

Harrison, C.K., Stone, J., Shapiro, J., Yee, S., Boyd, J.A., \& Rullan, V. (2009). The role of gender identities and stereotype salience with the academic performance of male and female college athletes. Journal of Sport and Social Issues, 33(1), 78-96. doi:10.1177/0193723508328902 
Hawkins, B. (2010). The new plantation: Black athletes, college sports, and predominantly White institutions. New York: Palgrave-MacMillan.

Hildenbrand, K., Sanders, J.P., Leslie-Toogood, A., \& Benton, S. (2009). Athletic status and academic performance and persistence at a NCAA division I university. Journal for the Study of Sports and Athletes in Education, 3(1), 41-58.

Journal of Blacks in Higher Education. (2008). Here is good news on Black student college graduation rates but a huge racial gap persists. Retrieved July 6, 2011, from http://www. jbhe.com/features/58_gradratesracialgap.html

Kim, M.M. (2002). Historically Black vs. White institutions: Academic development among Black students. Review of Higher Education, 25(4), 385-407. doi:10.1353/ rhe.2002.0019

Kim, M.M., \& Conrad, C.F. (2006). The impact of historically Black colleges and universities on the academic success of African American students. Research in Higher Education, 47, 399-427. doi:10.1007/s11162-005-9001-4

Kuh, G.D. (2001). Assessing what really matters to student learning: Inside the national survey of student engagement. Change, 33(3), 10-17, 66. doi:10.1080/00091380109601795

Lapchick, R. (2010). Keeping score when it counts: Assessing the 2010-11 bowl-bound college football teams - academic performance improves but race still matters. The Institute for Diversity and Ethics in Sport. Retrieved June 1, 2012 from http://www. tidesport.org/Grad\%20Rates/2010-11_APR-GSR_BowlStudy.pdf

Lapchick, R. (2011). Keeping score when it counts: Sweet 16 Men's and Women's teams a look at their academic success. The Institute for the Diversity and Ethics in Sport. Retrieved June 1, 2012 from http://www.tidesport.org/Grad\%20Rates/2011_Sweet_16_ FINAL.pdf

Lawrence, S.M. (2005). African American athletes' experiences of race in sport. International Review for the Sociology of Sport, 40(1), 99-110. doi:10.1177/1012690205052171

Lillig, J. (2009). "Magic" or misery?: HBCUs, guarantee contracts, and public policy. Journal of Sports Law \& Contemporary Problems, 6(41), 41-71.

Martin, B., Harrison, C.K., Stone, J., \& Lawrence, S.M. (2010). Athletic voices and academic victories: African American male student-athlete experiences in the Pac Ten. Journal of Sport and Social Issues, 34(2), 131-153. doi:10.1177/0193723510366541

NCAA. (2010a). Trends in graduation success rates and federal graduation rates at NCAA division I institutions Retrieved June 1, 2012 from http://www.ncaa.org/wps/wcm/ connect/f015f6004477d89f977cb749973c7da7/GSR+and+Fed+Trends+for+Web10_2 6_10+Final.pdf?MOD=AJPERES\&CACHEID=f015f6004477d89f977cb749973c7da7

NCAA. (2010b). Trends in academic success rates and federal graduation rates at NCAA division II institutions. Retrieved June 1, 2012 from http://www.ncaa.org/wps/wcm/con nect/3bb1a580445c6279813bb35b4796720/D2+Grad+Rate-ASR+Trends+RELEASE. pdf?MOD=AJPERES\&CACHEID=3bb1a580445c62a79813bb35b4796720

NCAA. (2011a). Information about the NCAA Division I federal graduation rates and NCAA graduation success rates reports Retrieved September 2, 2011, from http:// www.ncaa.org/wps/portal/ncaahome?WCM_GLOBAL_CONTEXT=/ncaa/ncaa/ academics+and+athletes/education+and+research/academic+reform/gsr/2009/874_ trw_d1_2009_report_info.html

NCAA. (2011b). Trends in academic success rates and federal graduation rates at NCAA division II institutions. Retrieved September 2, 2011 from http://www.ncaa.org/wps/ $\mathrm{wcm} /$ connect/public/NCAA/PDFs/2011/Trends+in+Academic+Success+Rates+and+ Federal+Graduation+Rates+at+NCAA+Division+II+Institutions

NCAA. (2011c). Who we are: Division II. Retrieved June 1, 2012 from http://www.ncaa. $\mathrm{org} / \mathrm{wps} / \mathrm{wcm} /$ connect/public/NCAA/Academics/Division+II/Who+We+Are

NCAA. (2012a). GSR/ASR Database. Retreived June 1, 2012 from http://fs.ncaa.org/Docs/ newmedia/public/rates/index.html

NCAA. (2012b). Revenue. Retrieved from http://www.ncaa.org/wps/wcm/connect/public/ NCAA/Finances/Revenue 
Nettles, M.T., \& Perna, L.W. (1997). Higher and adult education The African American education data book (Vol. I). Fairfax, VA: Frederick D. Patterson Research Institute of The College Fund/UNCF.

Palmer, R., \& Gasman, M. (2008). It takes a village to raise a child: The role of social capital in promoting academic success for African American men at a Black college. Journal of College Student Development, 49(1), 52-70. doi:10.1353/csd.2008.0002

Palmer, R., \& Young, E. (2010). The uniqueness of an HBCU enviornment: How a supportive campus climate promotes student success. In T.L. Strayhorn \& M.C. Terrell (Eds.), The evolving challenges facing Black college students: New insights for practice and research (pp. 138-161). Sterling, VA: Stylus.

Pascarella, E.T., Edison, M., Hagedorn, L.S., Nora, A., \& Terenzini, P.T. (1996). Influences of students' internal locus of attribution for academic success in the first year of college. Research in Higher Education, 37, 731-753. doi:10.1007/BF01792954

Pascarella, E.T., \& Terenzini, P.T. (2005). How college affects students: a third decade of research. San Francisco, CA: Jossey-Bass.

Person, D.R., \& LeNoir, K.M. (1997). Retention issues and models for African American male athletes. New Directions for Student Services, 80, 79-91. doi:10.1002/ss.8007

Ryan, G.W., \& Bernard, H.R. (2000). Data management and analysis methods. In N.K. Denzin \& Y.S. Lincoln (Eds.), Handbook of qualitative research (2nd ed., pp. 769-802). Thousand Oaks, CA: Sage.

Sack, A., \& Staurowsky, E.J. (1998). College athletes for hire: The evolution and legacy of the NCAA's amateur myth. Westport, CT: Praeger.

Sailes, G. (2010). Modern sport and The African American experience. San Diego, CA: Cognella.

Singer, J.N. (2005). Understanding racism through the eyes of African-American male student-athletes. Race, Ethnicity and Education, 8(4), 365-386. doi:10.1080/13613320500323963

Singer, J.N. (2008). Benefits and detriments of African American male athletes' participation in a big-time college football program. International Review for the Sociology of Sport, 43(4), 399-408. doi:10.1177/1012690208099874

Smith, E. (2009). Race, sport and the American dream (2nd ed.). Durham, NC: Carolina Academic Press.

Smith, C. (2012). NCAA tournament: First round's biggest financial winners and losers. Retrieved June 5, 2012 from http://www.forbes.com/sites/chrissmith/2012/03/17/ncaatournament-first-rounds-biggest-financial-winners-and-losers/

Steele, C.M. (2010). Whistling vivaldi: And other clues to how stereotypes affect us. New York, NY: W. W. Norton \& Company.

Strayhorn, T.L., \& Terrell, M.C. (2010). The evolving challenge of Black college students: New insights for practice and research. Sterling, VA: Stylus.

Taylor, D.L. (1995). A comparison of college athletic participants and nonparticipants on self-esteem. Journal of College Student Development, 36(5), 444-451.

Umbach, P.D., Palmer, M.M., Kuh, G.D., \& Hannah, S.J. (2006). Intercollegiate athletes and effective educational practices: Winning combination or losing effort? Research in Higher Education, 47(6), 709-733. doi:10.1007/s11162-006-9012-9

Whitt, E.J., Edison, M.I., Pascarella, E.T., Terenzini, P.T., \& Nora, A. (2001). Influences on student's openness to diversity and challenge in the second and third years of college. The Journal of Higher Education, 72(2), 172-204. doi:10.2307/2649321

Wolf-Wendell, L.E., Toma, D., \& Worphew, C.C. (2001). There's no "I" in Team: Lessons from athletics on community building. Review of Higher Education, 24(4), 369-396. doi:10.1353/rhe.2001.0012

Zimbalist, A. (2001). Unpaid professionals. Princeton, NJ: Princeton University Press. 